\title{
An empirical investigation on factors influencing on work stress: Evidence from banking industry
}

\author{
Alireza Davoudzadeh Moghaddam ${ }^{\mathrm{a}}$ and Yasaman Mashhadi Farahani ${ }^{\text {b* }}$
}

${ }^{a}$ Department of Management and Accounting, Tehran South Branch, Islamic Azad University, Tehran, Iran ${ }^{b}$ Department of Management, Tehran Central Branch, Islamic Azad University, Tehran, Iran

\section{H R O N I C L E}

\begin{tabular}{l}
\hline Article history: \\
Received March 18, 2015 \\
Received in revised format 28 \\
March 2015 \\
Accepted 29 May 2015 \\
Available online \\
May 30 2015 \\
\hline Keywords: \\
Work stress \\
Personal characteristics \\
Banking industry \\
\end{tabular}
\begin{abstract}
A B S T R A C T
An individual with a career faced with various career challenges may experience work-related stress. Work related stress is a factor that threatens employees' health. The most common negative consequences of stress are particularly the deterioration of performance and efficiency, decrease in productivity and quality of customer's services, which results in health problems. Work-related stress is a global issue, and banks are no exception. This paper presents a survey to investigate the influencing factors on work stress in banking industry. The study designs a questionnaire and distributes it among 200 randomly selected bank department managers in city of Tehran, Iran. Using principle component analysis, the study has detected five factors including organizational characteristics, external environment, work content, personal characteristics and top management.
\end{abstract}

\section{Introduction}

One of the most stressful periods of a normal day can be during working hours. Usually, workers spend about eight to ten hours at work, five or six days per week (Janipha et al., 2012), an individual with a career faced with various career challenges may experience work-related stress. Work related stress is a factor that threatens employees' health (Sert et al., 2014). The most common negative consequences of stress are particularly the deterioration of performance and efficiency, reduced productivity, decrease in quality of customer's services, health problems, frequent absence, accidents at work, use of alcohol and drugs, deliberately destructive behavior, e.g. spreading unconfirmed rumors and stealing (Happell et al., 2003; Perrewé et al., 2004, Quick et al., 1997; Banovcinova \& Baskova, 2014). Evidence associated with stress with illness has emerged from a variety of experimental, clinical and epidemiological research strategies which resulted in a vast literature (Steptoe, 1991; Masari et al., 2013). Menon and Akhliesh (1994) stated that stress could affect the individual's adjustment influencing performance and production of the entire organization (Hashim et al., 2012). It accounts for $50-60 \%$ of all lost working days (Persechino et al., 2013). Due to the destructive consequence of

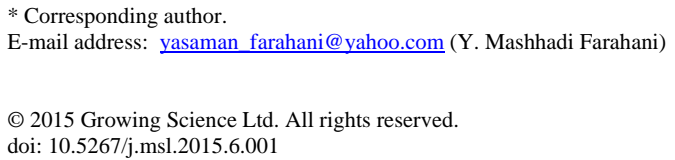


work stress in recent years, various international organizations have set initiatives to raise awareness regarding the psychosocial risks of work-related stress (Zoni \& Lugghini, 2012).

The stress literature offers so many "stress definition". However there are some differences, in common it is accepted that the individuals who are trying to fulfill the requirements over their capacities are under stress (Vermunt and Steensma, 2005; Sert et al., 2014). According to Lazarus and Folkman (1984), stress is a cognitive mediation between what is provided by an individual and his/her interaction with the environment. According to Lazarus (1995), stress can also be defined as the imbalance between people's perceived environmental demands and their perceived ability to cope with these demands (Elçi et al., 2012). Stress at the workplace has become an important issue because its consequences can take a heavy toll on organizations and their employees (Francis \& Barling, 2005; Hart \& Cooper, 2001; Tziner \& Sharoni, 2014) and even go beyond them, up to the level of the society at large (Petreanu et al., 2013). According to Seňová and Antošová (2014) "Stress is the second most commonly reported work-related problem, which affected 22 percent of employees in the European Union in 2005”. In the United Kingdom, 40\% of work-related illness is related to stress (Ly et al., 2014). In Japan situation seems to be more critical since more than $60 \%$ of employees are reported to suffer from anxiety and stress. According to the statistics, stress affects about one out of four workers. Stress involves not only personnel in leadership positions, but also it is a problem of everyone at any level (Seňová \& Antošová, 2014).

It should be noted that some degree of stress can be effective on increasing and improving individual's performance (Hasanvandi et al., 2013). However, once it exceeds a certain level, organization should expect a variety of negative consequences. The implications of work-related stress include the effects on worker satisfaction and productivity, their mental and physical health, absenteeism and its economic cost, the wider impact on family function and finally, the potential for employer liability (Tennant, 2001). Treven and Potocan (2005) stated that human resources loses 100 million workdays every year due to the aftermath of stress (Hashim et al., 2012). Mateescu and Chraif (2015) studied the relationship between job satisfaction, occupational stress and coping mechanism among employees of two organizations and determine whether there were differences between employees from educational organization and technical organization on these issues. They reported that there were significant differences between workers of the two firms on level of perceived stress, so the level of anxiety and stress were both higher for educational employees compared with those from technical organization, and the level of satisfaction from benefits was higher for employees from technical organization comparing to others.

As mentioned above, work-related stress is a global issue, and banks are no exception. Bank managers often fail to realize the impact of stress on employee performance which ultimately result in critical managerial dilemmas (Manea et al., 2013).

\section{Methodology}

This paper presents a study to find important factors influencing on work stress using factor analysis. The proposed study of this paper designs a questionnaire in Likert scale and distributes it among 200 bank department managers in the city of Tehran, Iran. Studies have been inducted in the following banks: Saderat, Pasargad, Karafarin, Shahr, Melat, Tejarat, Sarmayeh and Eghtesad Novin. Cronbach alpha is calculated as 0.85. In addition, Kaiser-Meyer-Olkin Measure of Sampling Adequacy test was equal to 0.88 and Chi-Square was measured as 1672.151, which validate the overall questionnaire. The questionnaire maintained 26 questions and since we plan to use factor analysis and this technique is sensitive to skewness we have decided to reduce the questions to 23. 


\section{The results}

The results of factor analysis have indicated that five factors of organizational characteristics, external environment, work content, personal characteristics and top management were considered as the most important factors influencing on employees' stress. Table 1 summarizes the results of our survey.

Table 1

The summary of factor analysis)

\begin{tabular}{|c|c|c|c|c|c|}
\hline Factor & Sub-Component & Weight & Eigenvalue & Variance & Accumulated \\
\hline \multirow{5}{*}{$\begin{array}{l}\text { Organizational } \\
\text { Characteristics }\end{array}$} & Favoritism & 0.728 & 2.55 & 13.42 & 13.42 \\
\hline & Values & 0.623 & & & \\
\hline & Organizational Justice & 0.61 & & & \\
\hline & Job Rotation & 0.593 & & & \\
\hline & Job Description & 0.512 & & & \\
\hline \multirow{3}{*}{$\begin{array}{l}\text { External } \\
\text { Environment }\end{array}$} & New Technology & 0.69 & 2.174 & 9.451 & 22.871 \\
\hline & Customer Expectation & 0.588 & & & \\
\hline & Economic & 0.575 & & & \\
\hline \multirow{3}{*}{ Work Content } & Workload & 0.71 & 1.697 & 8.933 & 31.804 \\
\hline & Commitment & 0.566 & & & \\
\hline & Shift Work & 0.513 & & & \\
\hline \multirow{4}{*}{$\begin{array}{l}\text { Personal } \\
\text { Characteristics }\end{array}$} & Individual Characteristics & 0.76 & 1.655 & 8.709 & 40.513 \\
\hline & Gender & 0.723 & & & \\
\hline & Tolerance & 0.574 & & & \\
\hline & Age & 0.537 & & & \\
\hline \multirow{3}{*}{ Top Management } & Leadership style & 0.767 & 1.641 & 8.635 & 49.148 \\
\hline & Role Conflict & 0.754 & & & \\
\hline & Evaluation Methods & 0.569 & & & \\
\hline
\end{tabular}

\section{Conclusion}

The results of Table 1 indicate there were five important factors influencing work stress in banking industry including organizational characteristics, external environment, work content, personal characteristics and top management. In terms of organizational characteristics, favoritism was number one priority followed by values, organizational justice, job rotation and job description. External environment was the second factor consists of three sub-components including new technology, customer expectation and economics. The third factor, work content, consisted of three factors including workload, commitment and shiftwork. Personal characteristics was the fourth factor, which included four sub-components including individual characteristics, gender, tolerance and age. Finally, top management was the last factor, which included leadership style, role conflict and evaluation methods.

\section{Acknowledgement}

The authors would like to thank the anonymous referees for constructive comments on earlier version of this work.

\section{References}

Banovcinova, L., \& Baskova, M. (2014). Sources of work-related stress and their effect on burnout in midwifery. Procedia-Social and Behavioral Sciences,132, 248-254.

Elçi, M., Şener, İ., Aksoy, S., \& Alpkan, L. (2012). The impact of ethical leadership and leadership effectiveness on employees' turnover intention: The mediating role of work related stress. ProcediaSocial and Behavioral Sciences,58, 289-297.

Francis, L., \& Barling, J. (2005). Organizational injustice and psychological strain. Canadian Journal of Behavioural Science/Revue canadienne des sciences du comportement, 37(4), 250.

Happell, B., Pinikahana, J., \& Martin, T. (2003). Stress and burnout in forensic psychiatric nursing. Stress and health, 19(2), 63-68. 
Hart, P. M., \& Cooper, C. L. (2001). Occupational stress: Toward a more integrated framework. Handbook of industrial, work and organizational psychology, 2, 93-114.

Hashim, A. E., Isnin, Z., Ismail, F., Ariff, N. R. M., Khalil, N., \& Ismail, N. (2012). Occupational stress and behaviour studies of other space: Commercial complex. Procedia-Social and Behavioral Sciences, 36, 752-759.

Hasanvandi, S., Valizade, M., Honarmand, M. M., \& Mohammadesmaeel, F. (2013). Effectiveness of stress management on mental health of divorced women. Procedia-Social and Behavioral Sciences, 84, 1559-1564.

Lazarus, R. S., \& Folkman, S. (1984). Stress. Appraisal, and coping, 725.

Ly, K. H., Asplund, K., \& Andersson, G. (2014). Stress management for middle managers via an acceptance and commitment-based smartphone application: A randomized controlled trial. Internet Interventions, 1(3), 95-101.

Janipha, N. A. I., Mustapha, A. A., \& Ismail, F. (2012). Workplace stress amongst consultants in practice. Procedia-Social and Behavioral Sciences,68, 183-191.

Masari, G. A., Muntele, D., \& Curelaru, V. (2013). Motivation, work-stress and somatic symptoms of Romanian preschool and primary school teachers. Procedia-Social and Behavioral Sciences, 84, 332-335.

Mateescu, A., \& Chraif, M. (2015). The relationship between job satisfaction, occupational stress and coping mechanism in educational and technical organizations. Procedia-Social and Behavioral Sciences, 187, 728-732.

Manea, C. N., Salceanu, C., Chiper, C., \& Chiper, I. (2013). Occupational stress and tolerance of bank employees. Procedia-Social and Behavioral Sciences, 92, 495-500.

Menon, N., \& Akhilesh, K. B. (1994). Functionally dependent stress among managers: a new perspective. Journal of Managerial Psychology, 9(3), 13-22.

Perrewé, P. L., Zellars, K. L., Ferris, G. R., Rossi, A. M., Kacmar, C. J., \& Ralston, D. A. (2004). Neutralizing job stressors: Political skill as an antidote to the dysfunctional consequences of role conflict. Academy of Management Journal, 47(1), 141-152.

Persechino, B., Valenti, A., Ronchetti, M., Rondinone, B. M., Di Tecco, C., Vitali, S., \& Iavicoli, S. (2013). Work-related stress risk assessment in Italy: A methodological proposal adapted to regulatory guidelines. Safety and health at work, 4(2), 95-99.

Petreanu, V., Iordache, R., \& Seracin, M. (2013). Assessment of work stress influence on work productivity in Romanian companies. Procedia-Social and Behavioral Sciences, 92, 420-425.

Quick, J. C., Quick, J. D., Nelson, D. L., \& Hurrell Jr, J. J. (1997). Preventive stress management in organizations. American Psychological Association.

Seňová, A., \& Antošová, M. (2014). Work stress as a worldwide problem in present Time. ProcediaSocial and Behavioral Sciences, 109, 312-316.

Sert, A., Elçi, M., Uslu, T., \& Şener, İ. (2014). The effects of organizational justice and ethical climate on perceived work related stress. Procedia-Social and Behavioral Sciences, 150, 1187-1198.

Steptoe, A. (1991). Psychological coping, individual differences and physiological stress responses.

Tennant, C. (2001). Work-related stress and depressive disorders. Journal of psychosomatic research, 51(5), 697-704.

Tziner, A., \& Sharoni, G. (2014). Journal of work and organizational psychology. Journal of Work and Organizational Psychology, 30(1), 35-42.

Vermunt, R., \& Steensma, H. (2005). How can justice be used to manage stress in organizations. Handbook of organizational justice, 383-410.

Zoni, S., \& Lucchini, R. G. (2012). European approaches to work-related stress: a critical review on risk evaluation. Safety and Health at Work, 3(1), 43-49. 